\title{
Problem komunikacji między kanclerzem wielkim koronnym a dworem w procesie tworzenia dokumentu w czasach Augusta II
}

Artykuł porusza problem komunikacji pomiędzy kanclerzem a dworem w procesie tworzenia się dokumentu na przykładzie działalności Jana Szembeka podkanclerzego, później kanclerza wielkiego koronnego. Podejmując badania nad kancelarią okresu saskiego stajemy wobec konieczności przeprowadzania podstawowych badań źródłowych z powodu braku literatury odnoszącej się do tego okresu ${ }^{1}$. Oczywiście istnieje bogata literatura dotycząca wspomnianych zagadnień z zakresu obiegu informacji, kręgu korespondentów, epistolografii, komunikacji społecznej ${ }^{2}$, omawiająca rozwój form kancelaryjnych ${ }^{3}$. Coraz więcej autorów analizuje pracę kancelarii nowożytnej, jednak ich zainteresowania odnoszą się do wcześniejszych okresów ${ }^{4}$. Wiele informacji ukazujących proces powstawania dokumentu, np. uniwersału i instrukcji na sejm, znajduje się w pracach monograficznych poświęconych dziejom politycznym tego okresu, a zwłaszcza parlamentaryzmowi, które z reguły omawiają aktywność kancelarii

${ }^{1}$ Największa liczba prac dotyczy okresu średniowiecza, a w dodatku są one bardzo zróżnicowane, gdyż obejmują studia nad kancelariami królewskimi, książęcymi, kościelnymi, miejskimi. Ponadto można do nich dodać badania nad dokumentem. Gorzej wygląda sytuacja w odniesieniu do czasów nowożytnych, a szczególnie okresu saskiego.

${ }^{2}$ J. Pirożyński, Z dziejów obiegu informacji w Europie XVI wieku. Nowiny z Polski w kolekcji Jana Jakuba Wicka w Zurychu z lat 1560-1578, Kraków 1995, „Zeszyty Naukowe Uniwersytetu Jagiellońskiego, MCLIV”, ,Zeszyty Historyczne”, Z. 115 zwłaszcza s.12-20 i 43-81; U. Augustyniak, Informacja i propaganda w Polsce za Zygmunta III, Warszawa 1981; Rozprawy z dziejów XVIII wieku. Z dziejów komunikacji socjalnej epoki nowożytnej, pod red. J. Wojtowicza, Toruń
1993.

${ }^{3}$ Odwołam się tylko do najnowszej pracy Stanisława Nawrockiego, Rozwój form kancelaryjnych na ziemiach polskich od średniowiecza do końca XX wieku, Poznań 1998 oraz J. Szymań-

${ }^{4}$ Np. A. Wyczański, Między kulturq a politykq. Sekretarze królewscy Zygmunta Starego History48, Warszawa 1990; M. Ferenc, ,Sekretarze nadworni” Zygmunta Augusta [w]: „Studia szawa 1995; 1977, z. 1; W. Krawczuk, Kancelaria koronna a sejm walny. Instructuarium, Warkrólewskiego, Księga ekspedycji kancelarii nadwornej 1559-1572. Materiały do dziejów dworu 
podczas przygotowywania sejmów ${ }^{5}$. Prezentowane niżej wnioski oparte są na korespondencji do kanclerza, której największy zbiór znajduje się w Bibliotece Czartoryskich w Krakowie ${ }^{6}$.

Warunki w jakich powstawały różne dokumenty kancelaryjne w czasach Augusta II różniły się bardzo w zależności od okresu jego panowania. Na znaczną część jego rządów przypada wojna północna i związane z tym zamieszanie wewnętrzne w kraju: panoszenie się obcych wojsk, detronizacja Augusta II, rządy Karola XII i Stanisława Leszczyńskiego, konfederacje sandomierska, warszawska, tarnogrodzka. W tym okresie podstawowym problemem było zapewnienie regularnej i bezpiecznej komunikacji pomiędzy królem, najważniejszymi urzędnikami Rzeczypospolitej i senatorami. Było to szczególnie trudne podczas natężenia prac związanego $\mathrm{z}$ okresami sejmowania, kiedy kancelaria musiała wysyłać setki dokumentów w odpowiednich, przewidzianych prawem okresach. Problem obiegu informacji był ważny przez cały okres rządów Augusta II. Król często przebywał w Saksonii, podróżował po kraju. Na zmieniające się miejsce pobytu dworu i urzędników należało przekazywać informacje z całego kraju. Przy dworze musieli przebywać najwyżsi urzędnicy, senatorowie, którzy mieli wpływ na podejmowane decyzje ${ }^{7}$.

W procesie powstawania dokumentu od projektowania poprzez wysłanie, zebranie koniecznych opinii $w$ danej sprawie, do przechowywania $w$ archiwum wielokrotnie zachodziła konieczność jego ekspedycji. Wymagało to zorganizowania systemu przesyłania różnorodnych informacji od najprostszych do tajnych. Nie chciałbym go tutaj szczegółowo określać, ale ze względu na temat artykułu najogólniej tylko wskażę na pewne jego cechy. Najbardziej powszechną formą przekazywania różnego rodzaju dokumentów (listy, projekty kopie aktów, gazetki itp.) było przesłanie ich pocztą ${ }^{8}$. Docierały do określonych osób na dworze np. kanclerza, podkanclerzego, marszałków, czy też osób, które odpowiadały za konkretne problemy np. feldmarszałka J. H Flemminga. Częstą praktyką było kierowanie listów do osób, które odpowiadały za kierowanie ich dalej. Takim adresatem byli np. sekretarze królewscy, którzy przekazywali wy-

${ }^{5}$ H. Olszewski, Sejm Rzeczypospolitej epoki oligarchii 1652-1763, Poznań 1966; Historia sejmu polskiego. t. I, pod red. J. Michalskiego, Warszawa 1984; J. A. Gierowski, Dyplomacja polska doby saskiej (1696-1763), [w:] Historia dyplomacji polskiej, t. II, Warszawa 1982; tenże, Między saskim absolutyzmem a złotq wolnościq, Wrocław 1953; J. Poraziński, Sejm lubelski w 1703 r. i jego miejsce $w$ konfliktach wewnętrznych na poczatku XVIII wieku, Warszawa 1988; B. Dybaś, Sejm pacyfikacyjny w 1699 r., Toruń 1991.

${ }^{6} 75$ tomów rękopisów od sygnatury 446 IV - korespondencja do kanclerza z lat 1697-1732. Poszczególne tomy znajdują się w innych bibliotekach min. Kórnickiej.

${ }^{7}$ M. Markiewicz, Rady senatorskie Augusta II (1697-1733), Kraków 1988.

${ }^{8}$ Istniała sieć osób i poczt, do których przesyłano listy i całe pakiety i dopiero z tej poczty wysyłane były do adresatów np. B. Czart. 474 s. 243 W. Sardi do J. Szembeka, Gdańsk 12 II 1719 pisze, że otrzymał „zwyczajny pakiet z Drezdy”, a s. 220 A. Dembowski do J. Szembeka kanclerza w. kor, Drezno 9 II 1718 donosił, że odebrał listy od niego osobne „bo się tamte w koperty zmieścić nie mogły". 
znaczonym osobom listy lub ich kopie, poszczególne informacje w nich zawarte, kopie dokumentów do nich załączonych ${ }^{9}$. Sekretarze odpowiadali za przygotowanie odpowiednich tłumaczeń dla króla, przekazanie sugestii kanclerza, a z powrotem przekazywali odpowiedzi króla. Było to istotne, gdyż często kanclerz i inni ministrowie Rzeczypospolitej znajdowali się poza dworem. W takim przypadku przygotowanie dokumentów (zwłaszcza najważniejszych) wymagało częstego korzystania z poczty zwykłej lub kurierskiej, ponieważ najpierw należało przygotować ich projekty, które przesyłano do akceptacji króla, a po zatwierdzeniu ostatecznego ich kształtu, odsyłano dla uzyskania podpisu królewskiego przed zapieczętowaniem itd.

Taki sposób postępowania narażał przewożone dokumenty na różnorodne niebezpieczeństwa, zwłaszcza w okresie, gdy na terenie kraju toczyła się wojna. Łatwo wtedy było o przechwycenie poczty, jej zniszczenie. Podejmowano odpowiednie środki zaradcze. Do typowych zabezpieczeń należały m.in. szyfrowanie relacji, liczbowanie kolejnych listów czy raportów dla upewnienia się, czy wszystkie dochodzą do adresata, dokonywanie odpisów i kopii, które przesyłano innymi drogami, powtarzanie informacji zawartych w poprzednich listach, wysyłanie pod kopertami innych osób itp. ${ }^{10} \mathrm{~W}$ odniesieniu do osób pełniących najważniejsze funkcje kontrolę obiegu informacji ułatwiała zasada regularnego pisania zgodnie z rytmem poczty, która odnosiła się też do osób wypełniających określone misje - poselstw, komisji itp. Powinni oni systematycznie zdawać relację do czasu zakończenia pełnienia funkcji i przekazania wypracowanych ustaleń ${ }^{11}$.

Autorzy listów do kanclerza stosowali środki powszechnie stosowane w ówczesnej korespondencji. Oprócz wspomnianej dbałości o regularność korespondencji starali się oni dokładniej podać kilka okoliczności ułatwiających kontrolowanie ciągłości i bezpieczeństwa korespondencji oraz drogi jaką przebywał list. Często określali, że właśnie odpowiadają na list wysłany konkretnego dnia, informując, jaką pocztą go otrzymywali. W ten sposób starali się kontrolować trasę i czas dostarczenia listu. Sami także często informowali adresatów, jaką pocztą (czy trasa) wysyłają swój list, podawali na jaki adres należy odesłać odpowiedź. Z reguły w treści listu informowali o załączonych do niego kopiach, odpisach listów innych osób, projektach, gazetkach pisanych i innych

${ }^{9}$ B. Czart. rkps. 475 s. 81 A. Dembowski do J. Szembeka, Drezno 9 VII 1718.

${ }^{10}$ Zabezpieczenia takie znane w całym okresie nowożytnym, konieczne były zwłaszcza w korespondencji urzędowej, dyplomatycznej. B. Czart. rkps. 474 s. 495 W. Sardi do J. Szembeka, Gdańsk 20 IV 1718, rkps 477 s. 335 A. Dembowski do J. Szembeka, Drezno 18 IX 1719. 11 Sekretarz A. Dembowski regularnie pisywał co środę i sobotę np. B. Czart. rkps. 473 s.
491 A. Dembowski do J. Szembeka, Drezno 21 VIII 1717. Korespondenci wzajemnie pilnowali czy pisują systematycznie, a jeśli występowały zakłócenia to zaraz wypominano je skarżąc się, że nie otrzymują listów lub odpowiedzi na własne pisma. Bardzo wiele przykładów takiego postępohetmanóna znaleźć w listach do kanclerza pisanych przez podskarbiego J. Przebendowskiego, ciekawew A. Sieniawskiego, M. Rzewuskiego i innych. Często autorzy informują, że nie mają nic wego do doniesienia i piszą tylko dla utrzymania „cursus correspondencyi”, 
materiałach. Podawali także dodatkowe informacje, które uważali za istotne. Najczęściej było to w przypadku, gdy list docierał przez specjalnych kurierów, umyślnych, kiedy korzystano z usług osób jadących na najbliższą pocztę, czy do miejsca pobytu adresata ${ }^{12}$.

Pamiętając o złożoności sytuacji politycznej towarzyszącej powstawaniu dokumentu, interesujące będzie prześledzenie różnych etapów procesu jego tworzenia. Najpierw pojawiał się problem, kto sporządzał jego projekt. Zależało to od wielu czynników: od treści i rodzaju dokumentu, jego wagi, od osoby która zleciła wykonanie dokumentu itp. Często projekt dokumentu, a nawet jego ostateczna forma przygotowywana była przez zleceniodawcę i przedstawiana kanclerzowi do dalszej pracy nad nim. Przy sporządzaniu treści dokumentu zazwyczaj pojawiała się konieczność wyjaśnienia okoliczności i uwarunkowań decydujących o jego wystawieniu, dlaczego zawarto w nim takie informacje i dlaczego powinny być użyte takie sformułowania, kim jest osoba dla której wystawia się dany dokument itp.

Przy pisaniu treści różnych dokumentów korzystano z przykładów znajdujących się w istniejących już księgach kancelaryjnych, w typowych księgach pomocniczych używanych przez kancelarię. Niewątpliwie takie księgi mieli także inni ministrowie, np. marszałkowie i wszystkie osoby, które musiały tworzyć dokumenty. Ich kancelarie, sekretarze i pisarze za pomocą tych ksiąg określali tak istotne elementy, jak np. formę dokumentu, tytulaturę. Często bowiem wraz z prośbą np. o urząd, nadanie dóbr pojawiała się informacja, że w załączeniu jest już gotowy do podpisu dokument, sugerowano na jakie nazwisko wystawić dany przywilej ${ }^{13}$.

W wielu przypadkach pojawiała się konieczność skonfrontowania, czy dany dokument był istotnie wydany, odnosiło się to zwłaszcza do przywilejów. Na przykład w odpowiedzi na żądanie o sprawdzenie, czy dany przywilej wyszedł z kancelarii sekretarz A. S. Dembowski pisał: „nie mam w regestrze, musiał być dawniej przede mną pisany" ${ }^{\prime 4}$. Problem należało wyjaśnić, co zajmowało trochę czasu, gdyż często nie było pod ręką ksiąg kancelarii. Czasem konieczne było

12 Takie informacje znajdują się praktycznie w każdym liście i one zdają się być charakterystyczna cechą tej urzędowej korespondencji.

${ }^{13}$ Ministrowie, senatorowie musieli dysponować takimi materiałami w swojej kancelarii. Ministrowie mieli swoje osobne kancelarie, gdzie redagowano konieczne dokumenty. W nich znajdowały się na pewno wzory dokumentów, formularze. Np. w Bibliotece PAN w Krakowie zachowało się kilkanaście ksiąg zawierających wzory różnego rodzaju listów, przywilejów używanych w kancelarii Mniszchów, będących marszałkami w okresie saskim. Można założyć, że właściwie u większości aktywnych politycznie lub gospodarczo osób znajdowały się tego rodzaju materiały (w mniejszej, lub większej skali), gdyż konieczne były one w załatwieniu własnych spraw, które forsowano różnymi drogami.

${ }^{14}$ B. Czart. rkps 474 IV s. 127 list A. S. Dembowskiego do J. Szembeka kanclerza w. kor., Drezno 29 I 1718. 
zapoznanie się z oryginałem, który trudno było znaleźć w księgach, a mogli go mieć np. hetmani ${ }^{15}$.

Przy sporządzaniu dokumentów musiały istnieć różne procedury, jednak na tym etapie badań nie można jeszcze opisywać ich dokładniej. Często przygotowywany projekt przedstawiono ,ad deferendum królowi” już w fazie projektowania treści. Przed prezentacją dokument powinien być przetłumaczony na język francuski - najczęściej, gdy wychodził w języku polskim. Nie wiemy czy tłumaczono także dokumenty, które wydawano po łacinie. Znajdujemy wiele brudnopisów różnych dokumentów: instrukcji, uniwersałów, listów, często w kilku wersjach świadczących o pracy nad przygotowaniem ostatecznej wersji tak po francusku, jak i po polsku ${ }^{16}$. Zresztą konieczność tłumaczenia otrzymywanych i wysyłanych dokumentów niejednokrotnie stanowiła istotną przeszkodę w terminowym wykonaniu projektu dokumentu. Tłumacze musieli być zatrudnieni nie tylko przy dworze, ale także np. przy hetmanach, a nie zawsze byli w zasięgu ręki. Po odczytaniu królowi, lub po tym jak król zapoznał się z nim, projekt dawany był kancelarii do przepisania ${ }^{17}$. Zdarzało się, że kanclerz nie miał dostępu do przygotowywanych dokumentów, albo dostęp ten był ograniczony. Sekretarz A. Dembowski donosił na przykład, że nie miał dostępu do treści, gdyż dokument był już zapieczętowany. Innym razem pisał, że przepisywał tajną instrukcję do wysłania, a wtedy król i nuncjusz zobowiązali go, by nikomu jej nie pokazywał. Jednak nuncjusz pozwolił donieść kanclerzowi główne problemy ${ }^{18}$.

Decyzja króla mogła wpłynąc na tok prac nad powstającym dokumentem i było to w jakiś sposób odnotowywane. Na przykład przy wystawianiu przywilejów znajdujemy określenia: że król nie chciał podpisać przywilejów, ale „kazał nanotować oneż do dalszej swojej dyspozycji”, „na wsie ruskie otrzymałem deklaracją in favorem JmP stolnika koronnego", otrzymałem ,deklaracją czy też podpis (nie wiem) na starostwo wiślickie"19, ustnie „odebrałem fiat"20. Innym razem sekretarz musiał kursować między wieloma osobami na dworze zanim mógł sporządzić jakiś tekst lub uzyskać odpowiednie podpisy ${ }^{21}$. Trzeba tutaj zaznaczyć, iż często już w fazie dyskusji nad przygotowaniem odpowiednich

${ }^{15}$ Tak bywało na przykład w odniesieniu do spraw z Turcją. W tym przypadku hetmani często posiadali oryginalne listy, porozumienia, traktaty. Zwykle hetmani przesyłali kopie listów do kancelarii kor. Jednak znajdujemy wiele wzmianek, że przesyłają też np. oryginały listów, ale proszą o odesłanie ich po zrobieniu kopii.

${ }^{16} \mathrm{~W}$ wielu przypadkach widoczne jest, że projekty przechodziły prze wiele rąk. Pisane były w odpowiedni sposób - połowę karty, jej lewą część zostawiano na uwagi. Zachowały się także projekty pisane osobiście przez kanclerza z licznymi poprawkami.

${ }^{17}$ B. Czart. rkps 474 s. 50 A. Dembowski donosił J. Szembekowi, że instrukcję skopiował po odczytaniu królowi i przesyła mu jej treść.

${ }_{19}^{18}$ B. Czart. rkps 474 s. 75 list Dembowskiego z Drezna 26 I 1718 i s. 130 list z 28 I 1718.

${ }^{19}$ B. Czart. rkps 474 s. 249, 251 A. Dembowski z Drezna 12 II 1717.

20) Ibid., s. 271.

Ibid., s. 57 i n., s. 429. 
dokumentów na dworze konieczna była obecność Polaków. Z tym nieraz bywało źle. Nawet będąc w Rydzynie Dembowski martwił się, że król będzie miał u boku tylko trzech Polaków i „,mnie też czwartego"22.

W przypadku niektórych dokumentów, po dyskusjach na dworze i przygotowaniu projektu konieczne były szersze konsultacje. Często wymagała tego waga problemu lub chęć zasięgnięcia opinii znawcy w danej sprawie. Niekiedy ponadto wymagało tego prawo. Należało więc na przykład uzyskać opinie senatorów przed wysłaniem ostatecznej wersji uniwersału i instrukcji na sejm. Bez problemu można by było przytoczyć tutaj wiele różnych opinii, a nawet dyskusji nad projektami takich dokumentów przygotowywanych do ekspedycji ${ }^{23}$. Niejednokrotnie zdarzało się, że projekt wstępnie przygotowany wysyłano do kanclerza, aby ten zaakceptował, lub dołożył jakieś sprawy. Wydłużało to dodatkowo okres przygotowania dokumentu ${ }^{24}$. W praktyce oznaczało to jednak konieczność przesyłania różnych informacji pomiędzy zainteresowanymi osobami, które wyjaśniały konkretne problemy, wskazywały miejsca lub osoby, u których można było by znaleźć żądane informacje, lub które sugerowały sposób rozwiązania problemu.

Jak wspomniano, do przesłania tych informacji oraz projektów dokumentów wykorzystywano pocztę zwykłą lub specjalną różnych ludzi udających się do miejsc, w których spodziewano się znaleźć adresata listu - gońców, umyślnych itp. Czasem oznaczało to, że kilka kopii projektu dokumentu obywało długą wędrówkę do różnych osób i miejsc. W czasie tych podróży narażone były one na zaginięcie, przechwycenie itp. Często zachodziła konieczność zastosowania szyfrów, przetłumaczenia itp. Wszystkie te czynniki mogły opóźnić ostateczne przygotowanie dokumentu. Zdarzało się bowiem, że autor listu lub jego adresat nie mieli przy sobie szyfru, którym mogliby się posłużyć ${ }^{25}$ lub też poszukiwano zaufanego człowieka do przesłania informacji ${ }^{26}$, itp.

Problemy mogły się pojawić również w związku z zastosowaniem odpowiedniej tytulatury. Nie zawsze było tak jak pisał A. Dembowski, że „król kazał mi sobie przynieść tytuły, jakie daje sam cesarzowi i papieżowi, com zaraz

22 Ibid., s. 720 Dembowski do J. Szembeka, Rydzyna 12 VI 1718. Podczas bytności króla w kraju, gdy było wiele senatorów można było zaprezentować projekty i od razu podjąć decyzje, zob. Relacja wydarzeń we Wschowie 16 XII 1717 w: Wojewódzkie Archiwum Państwowe w Krakowie o/Wawel Archiwum Sanguszków rkps 422, t. II s. 245 in.

${ }^{23}$ Ibid., s. 451 F. Szaniawski bp kujawski, Smardzewice 7 IV 1718 pisał, że prymas , instrukcje in toto approbował, nie pretendując żadnego addydamentu...”, s. 625 J. Przebendowski podskarbi w. kor. z Radomia 29 IV 1718 pisał krótko „ekspedycję kurlandzką per omnia approbuję”. Oczywiście największe możliwości konsultacji dawała Rada Senatu, zob. M. Markiewicz, Rady...

${ }^{24}$ Ibid., s. 821 Dembowski w liście z 25 VI 1718 przypominał, że przesłał projekt ekspedycji i pyta czy ma dołożyć jakieś nowe sprawy.

${ }^{25}$ Ibid., list Ponińskiego starosty kopanickiego z Moskwy 17 III 1718.

${ }^{26} \mathrm{Ibid}$., s. 203 J. Mniszech marszałek wielki kor., Drezno 5 II 1718 informował kanclerza J. Szembeka, że wysyła metrykanta F. Cichockiego z tajnymi listami. 
uczynił" ${ }^{27}$. Czasem wiele czasu zajmowało znalezienie odpowiednich wzorów, zwłaszcza gdy należało wysłać listy do osób, do których rzadko pisano lub wystawić dokumenty rzadziej wydawane. Wówczas istniała konieczność poszukiwania odpowiedniej tytulatury stosowanej w takich przypadkach, wyjaśniania pojęć, często przy zaangażowaniu różnych kancelarii i osób ${ }^{28}$.

Po sporządzeniu dokumentu otwierał się nowy problem - uzyskanie podpisu. Niejednokrotnie po tym jak król zgodził się na wydanie np. przywileju, czy zgodził się z treścią listu, mógł odwlekać moment podpisania przygotowanych dokumentów. W korespondencji Dembowskiego wielokrotnie znajdujemy wzmianki, że czekał na podpis pół dnia, cały dzień, czasem bez skutku. Innym razem król podpisał tylko niektóre dokumenty, a innych nie chciał podpisać. Nieraz musiał się on uciekać do czekania na dobry humor króla, czasem najpierw musiał uzyskać zgodę na pojawienie się z dokumentami itp. ${ }^{29}$.

Osobnym problemem były wymogi prawa, które nakazywały podpisywanie pewnych dokumentów tylko na terytorium Polski. Niejednokrotnie nie było to możliwe. Posuwano się wówczas do antydatowania czasu wystawienia dokumentu, po to by wpisać miejsce znajdujące się na terenie Rzeczypospolitej, najczęściej Wschowę. Jednak w wielu przypadkach król musiał po prostu przyjechać do Polski tylko po to, by podpisać ekspedycję. Niejednokrotnie komplikowało to sprawy.

Po sporządzeniu dokumentu i jego podpisaniu należało go zapieczętować odpowiednią pieczęcią. W omawianym okresie wystawiano dokumenty pisane ręcznie przez kancelarie, jak też drukowane (np. instrukcje, uniwersały). Należy pamiętać, że jeszcze na tym etapie mogło dochodzić do pomyłek, co wymagało np. powtórnego drukowania dokumentu. Różne też były typy pieczęci stosowane do ich zamknięcia (odnosiło się to także do listów) ${ }^{30}$.

Tak jak w przypadku poprzednich etapów prac nad dokumentem, nie stanowiło to problemu, gdy u boku króla przebywali kanclerze, lub sekretarze pieczęci. Jednak czasem nie było to możliwe i znowu pojawiały się problemy. Było to szczególnie niebezpieczne, gdy dotyczyło korespondencji dyplomatycznej, która wymagała przestrzegania pieczętowania dokumentu odpowiednimi pieczęciami. Nieraz zdarzało się też, że z różnych powodów kanclerze zwlekali z

${ }^{27}$ B. Czart. rkps 474 A. Dembowski do J. Szembeka z Drezna 29 I 1718.

${ }^{28}$ Wówczas zwracano się z prośbą do innych urzędników, lub poszukiwano dokumentów

wydawanych dawniej dla tych osób, aby sprawdzić precedens.
${ }^{29} \mathrm{~Np}$. Dembowski pisał z Drezna, że król nie chciał ponownie podpisać dwóch przywilejów z okienkami "mówiąc, żeby je wprzód zapisać. Zaraz się porwał nie chcąc i drugich podpisać..."w B. Czart. rkps 473 s. 378 list z 4 VIII 1717 do kanclerza J. Szembeka. ${ }_{k}^{30}$ Nów polskich, Kraków 1919; M. Gumowski, M. Haisig, S. Mikucki, Sfragistyka, Warszawa
1960. 
przyłożeniem pieczęci pod jakiś dokument, lub dochodziło do sporu pod jaką pieczęcią miał być wydany ${ }^{31}$.

Zresztą wiąże się z tym także inny problem. Niejednokrotnie zwłoka z wystawieniem, lub zapieczętowaniem dokumentu wiązała się z szerszym podziałem kompetencji. Przed zapieczętowaniem dokumentu, należało bowiem upewnić się, czy jego treść nie jest zastrzeżona do kancelarii hetmańskiej, prymasowskiej, czy już poprzednio nie obiecano np. przywileju komu innemu. Odnosiło się to zwłaszcza do przywilejów „z okienkiem”, czyli takich, w których wpisywano osobę dla której był wystawiony ${ }^{32}$.

Na szczególną uwagę zasługuje sposób archiwizowania wystawionych dokumentów. Sposoby przechowywania dokumentów, organizacji ksiagg np. notowanie liczby stron, podpis odpowiedniego metrykanta, sporządzanie ksiąg, pomocniczych, regestrów itp. Omawiane są w literaturze, chociaż wiele spraw zostaje jeszcze otwartych. Jeśli chodzi o kancelarię koronną najważniejsze były oczywiście różnego rodzaju księgi metryki koronnej ${ }^{33}$ i $\operatorname{archiwum~}^{34}$. Niemniej ważne, jak już poprzednio wspomniałem, były także archiwa poszczególnych urzędników hetmanów, podskarbich itp. Na koniec można jeszcze wspomnieć 0 archiwach grodzkich i ziemskich ${ }^{35}$.

Tutaj dotykamy także zagadnienia sposobu publikowania dokumentu. Przy takiej ilości i różnorodności wystawianych dokumentów kancelaria musiała pamiętać, że publikowano je w różny sposób, w zależności od danego typu oraz o tym, że istniały często odpowiednie terminy publikacji np. w przypadku sejmów, sejmików, komisji. Są to sprawy powszechnie znane i nie należy tutaj zagłębiać się w szczegóły. Wspominam o nich jednak w kontekście ważności dokumentu. Niedotrzymanie sposobu i terminu publikacji narażało bowiem kancelarię na liczne kłopoty. Z drugiej strony kancelaria musiała sporządzać aktualne listy osób, do których powinna adresować przygotowane już dokumen-

${ }^{31}$ Czasem w księgach zaznaczano nietypowe wypadki pieczętowania, np. pod kopią listu Augusta II do króla Prus ze Wschowy 11 XII 1717 r. metrykant zaznaczył „NB. pod pokojową pieczęcią wychodził ten list”, w: WAP Kraków o/Wawel Arch. Sang. rkps 422, t. II, s. 231.

${ }^{32} \mathrm{Na}$ przykład podkanclerzy koronny mówił do Dembowskiego ,żaląc się, że tu nie jest tej miary tylko quam statua, że mu niczego nie komunikuję”, że powinien być równy kanclerzowi, że nie od niego wychodzą ekspedycje tylko od barona Manteuffla i Dembowskiego. [w:] B. Czart. rkps 473 s. 346, 348 list Dembowskiego do J. Szembeka, Drezno 30 VII 1717.

${ }^{33}$ Najważniejsze informacje [w:] Inwentarz Metryki Koronnej, oprac. I. SułkowskaKurasiowa, M. Woźniakowa, Warszawa 1973, także I. Sułkowska, Ksiegi wpisów Metryki Koronnej (1447-1795) w Archiwum Gtównym Akt Dawnych, [w:] „Archeion”, XLIV 1966.

${ }^{34}$ J. Lileyko, Zamek warszawski. Rezydencja królewska i siedziba władz Rzeczypospolitej 1569-1763, Warszawa 1983, zwłaszcza od s. 290.

${ }^{35}$ Różnorodna literatura np. O. Balzer, O kancelarii i aktach grodzkich XVIII w., [w:] Przewodnik naukowy i literacki, 1888; J. Bielecka, Organizacja i działalność kancelarii ziemskich $i$ grodzkich wielkopolskich, [w:] „Archeion” XXII, 1956; Kancelarie okresu księgi wpisów w Prusach Królewskich, red. A. Tomczaka, Warszawa 1994. 
ty. Niejednokrotnie dochodziło wówczas do komplikacji, związanych np. z nieobsadzeniem danego urzędu ${ }^{36}$.

Nawet zakończenie prac nad dokumentem nie oznaczało jeszcze, że skończyła się praca nad nim (pomijam tu oczywiście sprawę błędów i wynikającej stąd konieczności ponownego przygotowania dokumentu). Niejednokrotnie kancelaria musiała przygotowywać nowy dokument, gdyż np. pierwsze instrukcje wydane w jakiejś sprawie „,nie wzięły skutku swego" ${ }^{37}$. Innym razem istniała konieczność wydania kolejnych instrukcji wynikających z rozwoju sytuacji, np. podczas pełnienia misji dyplomatycznej. Jeszcze kiedy indziej, wydanie jednego dokumentu wymagało zmiany innych. Np. na prośbę hetmana Sieniawskiego kancelaria koronna wydała reskrypt Augusta II do wojska, ,żebyście post publicationem niniejszego listu naszego, każdy z Uprzejmości i Wierności Waszych list swój przypowiedny z kancellaryi naszej pierwej sobie wydany do rąk JW kasztellana krakowskiego h. w. k. in originali powróciwszy, taki drugi na osobę swoją z podpisem naszym i pieczęcią koronną authentyczną od niegoż odebrał..., 38

Niejednokrotnie wydane dokumenty wymagały wyjaśnienia, a niektórym nie wystarczała pisemna interpretacja. Na przykład w styczniu 1718 r. M. Ossoliński i W. Kiciński przybyli specjalnie do Drezna "chcąc mieć od Króla Jmci objaśnienie w niektórych trudnościach novi regulaminis dworu i król Jmc. naznaczył im na jutro conferencya...."39. Innym razem Dembowski donosił, ze Żydzi ze starostwa kowelskiego skarżyli się na podstarościego, podali odpowiednie pismo do króla i przyjechali osobiście domagając się instrukcji na komisję. Dembowski starał się tłumaczyć, ze ma teraz związane ręce i twierdził, że powinien się odwołać do kanclerza J. Szembeka dodając: ,jakoż pewnie przewłokę aż do informatiej WMPana Dobrodzieja"40.

Ten skromny katalog przedstawionych wyżej problemów pozwala zauważyć, jak wiele różnych czynników wpływało na powstanie dokumentu. W tym przypadku, czyli w okresie unii polsko-saskiej dochodziły jeszcze problemy funkcjonowania dwóch odrębnych państw, co niewątpliwie komplikowało sytuacje prowadzące do różnorodnych relacji pomiędzy administracjami obu państw. Wydaje się, że na podkreślenie zasługuje fakt, iż w tych warunkach proces tworzenia dokumentu nie mógł zamknąć się tylko w obrębie kancelarii i

${ }^{36}$ Tak bywało np. w przypadku ekspedycji sejmowej, którą należało kierować do odpowiednich osób, grodów, w odpowiednim czasie itp.. Np. H. Olszewski, Sejm...; W. Kriegseisen, Sejmiki Rzeczypospolitej szlacheckiej w XVII i XVIII wieku, Warszawa 1991; Achremczyk S., Reprezentacja stanowa Prus Królewskich w latach 1696-1772. Skład spoteczny i dziatalność, Olsztyn
1981.

${ }^{37}$ WAP Kraków o/Wawel Arch. Sang. rkps 422 t. II s. 232 konieczność wydania nowej instrukcji dla F. Ponińskiego starosty kopanickiego w sprawie ewakuacji wojsk.

${ }_{38}$ Ibid., s. 23 . Wynikało to z zawartego traktatu i sejmu niemego. Tutaj szczegółowy opis, a
na s. 21 kopie takich listów przypowiednich.

${ }_{40}^{39}$ B. Czart. rkps 474, s. 39 A. Dembowski do J. Szembeka, Drezno, 19 I 1718 r.

Ibid., s. 226 A. S. Dembowski do J. Szembeka, Drezno, 9 II 1718. 
jej urzędników. Stale był narażony na ingerencję różnych czynników, które pogłębiały i tak duże trudności organizacyjne wynikające $\mathrm{z}$ rozproszenia geograficznego i sposobu funkcjonowania Rzeczypospolitej.

Podsumowując ten krótki przegląd wybranych problemów, sprowadzających się do problemu komunikacji i relacji pomiędzy różnymi grupami biorącymi udział w różnych etapach tworzenia dokumentu, należy podkreślić, że jest to tylko bardzo wstępny zarys tej problematyki. Pozostaje do postawienia bardzo wiele pytań. Główne z nich wiążą się z funkcjonowaniem kancelarii jednego z najważniejszych urzędów, jakim był urząd kanclerza. Dopóki nie powstaną prace na ten temat, to większość wniosków będzie bardzo niepewna. Inne wiążą się z relacjami król-kanclerz. Należałoby też dokładniej zbadać rolę innych urzędników centralnych, ich kancelarie i sposób funkcjonowania. Poza tym pojawia się wiele pytań natury ogólniejszej, częściowo poruszanych w syntezach, np. H. Izdebskiego i J. Malca i poświęconych administracji: problem biurokratyzacji, procedur (np. sprawa protokołów), korpusu urzędniczego, nowoczesnej administracji, porównań z sytuacją w Europie tego okresu. 